\title{
COMPARATIVE STUDY ON PRODUCTION OF $\alpha$-AMYLASE FROM BACILLUS LICHENIFORMIS STRAINS
}

\author{
Dibu Divakaran; Aswathi Chandran; Pratap Chandran R*
}

Department of Biotechnology and Research, K. V. M. College of Engineering and Information Technology, Kokkothamangalam P. O., Cherthala - 688583, Alappuzha District, Kerala, India.

Submitted: November 27, 2010; Approved: June 06, 2011.

\begin{abstract}
Alpha amylase ( $\alpha$-1, 4-glucan-glucanhydrolase, EC 3.2.1.1), an extracellular enzyme, degrades $\alpha, 1-4$ glucosidic linkages of starch and related substrates in an endo-fashion producing oligosaccharides including maltose, glucose and alpha limit dextrin (7). The present study deals with the production and comparative study of production of $\alpha$-amylase from two strains of Bacillus licheniformis, MTCC 2617 and 2618, by using four different substrates, starch, rice, wheat and ragi powder as carbon source by submerged fermentation. The effect of varying $\mathrm{pH}$ and incubation temperature, activator, inhibitor, and substrate concentration was investigated on the activity of $\alpha$-amylase produced by MTCC strain 2618 . The results shows that the production of the $\alpha$-amylase by the B.licheniformis strain MTCC 2618, using four different substrates were found to be maximum (Starch $3.64 \mathrm{IU} / \mathrm{ml} /$ minutes, Rice powder $2.93 \mathrm{IU} / \mathrm{ml} / \mathrm{minutes}$, Wheat powder $2.67 \mathrm{IU} / \mathrm{ml} /$ minutes, Ragi powder $2.36 \mathrm{IU} / \mathrm{ml} /$ minutes) on comparing the enzyme production of two strains. It was also observed that the maximum production was found on the $3^{\text {rd }}$ day (i.e. $72 \mathrm{hr}$ ) and characterization of crude enzyme revealed that optimum activity was at $\mathrm{pH} 7$ and $37^{\circ} \mathrm{C}$.
\end{abstract}

Key words: amylase; Bacillus licheniformis; enzyme; extracellular; glucose.

\section{INTRODUCTION}

Amylase is an enzyme that breaks down starch into sugar. Starch, the primary storage polysaccharide, is an important constituent of the human diet and, for this purpose, it is enzymatically processed into a variety of different products (20). It is degraded by amylolytic enzymes. Although amylases originate from different sources (animals, plants and microorganisms), microbial amylases generally meet industrial demands best, due to their short growth period and productivity
(6). Its extensive application in food, starch liquefaction, saccharification, detergent, brewing, paper, textile and distilling industries, has led to a greater stress for the increase in the indigenous production of $\alpha$-amylase (12). With the advent of new frontiers in biotechnology, the spectrum of amylase application has expanded into many other fields, such as clinical, medical and analytical chemistry.

Many of the enzymes used in the industries are extracellular derived from microorganisms. Among various extracellular enzymes, $\alpha$-amylase ranks first in terms of

\footnotetext{
*Corresponding Author. Mailing address: Department of Biotechnology, K. V. M. College of Engineering and Information Technology, Kokkothamangalam P. O. Cherthala - 688583, Alappuzha District, Kerala, India.; Fax.: ++91- 0478 2811707.; E-mail: drpratapchandran@yahoo.co.in
} 
commercial exploitation. Bacteria and fungi secrete amylases to the outside of the cells to carry out extra cellular digestion. When they have broken down the soluble starch, the soluble end products such as (glucose or maltose) are absorbed into their cells. Demand for microbial amylases has increased, due to their specificity of reaction, mild conditions required for the reaction, and less energy consumption than the conventional chemical methods. The industrially important Bacillus strains, which are extensively used to produce alpha amylase, are $B$. amyloliquefaciens, B. licheniformis (10), B. stearothermophilus (25), B. subtilis (21), B. megaterium (5) and B. circulans (22).

Previously many works have been carried out for the production of $\alpha$-amylase using different media compositions with varying substrates using the Bacillus sp. The important substrate used was starch $(15,22)$ with varying media compositions. The other substrates included banana peel (19) wheat bran and rice flake manufacturing wastes (1).

Bacillus licheniformis is a Gram-positive endospore forming organism that can be isolated from soils and plant material all over the world. This organism is used extensively for large-scale industrial production of exoenzymes as it can secrete large quantities of proteins of up to $20-25 \mathrm{~g} / \mathrm{l}$. The use of the submerged culture is advantageous because of the ease of sterilization and its process control.

The objective of this work was to study the pattern and the comparison of $\alpha$-amylase production by using two strains of Bacillus licheniformis, MTCC 2617 and MTCC 2618 using four different substrates starch, rice, wheat and ragi powder as carbon source. Ragi (Eleusine coracana) or finger millet is round, soft yet firm and rich brown in color. It is probably the only edible solid you are advised to swallow not chew. A gram of ragi has $72 \%$ carbohydrate, $3.6 \%$ fiber, $7.3 \%$ of protein, vitamin $\mathrm{B}$ and a good combination of minerals

\section{MATERIALS AND METHODS}

\section{Microorganisms and Maintenance of Culture}

Bacillus licheniformis strain MTCC 2617 and MTCC
2618 were procured from Microbial Type Culture Collection (MTCC) Chandigarh and grown on nutrient agar slants at $37^{\circ} \mathrm{C}$ and subcultured every month.

\section{Inoculum and Production Media}

The inoculum was prepared by the addition of sterile distilled water in to the freshly grown agar slants, from this $0.5 \mathrm{ml}$ of suspension was inoculated in to $100 \mathrm{ml}$ of sterilized fermentation medium and incubated in a shaking incubator at $100 \mathrm{rpm}$ at $37^{\circ} \mathrm{C}$. The composition of media was $(\mathrm{g} / \mathrm{l})$ Bacteriological peptone $-6 \mathrm{~g}, \mathrm{MgSO}_{4} .7 \mathrm{H}_{2} \mathrm{O}-0.5 \mathrm{~g}, \mathrm{KCl}-0.5 \mathrm{~g}$, Substrate - $1 \mathrm{~g}$ (24). For the production of the enzyme, broths were prepared using four different substrates Starch, Rice, Wheat and Ragi powder.

The activity of the enzyme produced in the media was checked using enzymatic assay method at regular time intervals of $24 \mathrm{~h}, 48 \mathrm{~h}, 72 \mathrm{~h}, 96 \mathrm{~h}$ and $120 \mathrm{~h}$ respectively, to find the time period and the medium with the substrate that showed the highest enzyme production.

\section{Extraction of the $\alpha$-Amylase Enzyme}

After incubation, the culture broth was centrifuged at 5000 rpm for 20 minutes at $4^{\circ} \mathrm{C}$. The supernatant was collected and the amylase activity was estimated (24). The supernatant was further purified to obtain the crude enzyme. The crude enzyme was further purified by ammonium sulfate precipitation, dialysis and ion- exchange chromatography to obtain pure enzyme.

\section{CHARACTERIZATION OF ENZYME}

\section{Effect of pH on Enzyme Activity}

The amylases produced by several Bacillus sp. have a variety of $\mathrm{pH}$ profiles. When the $\mathrm{pH}$ is altered below or above the optimum the activity is decreased. The effect of $\mathrm{pH}$ on the activity of amylase was determined by preparing different $\mathrm{pH}$ buffers ( $\mathrm{pH} \mathrm{3,} \mathrm{5,} \mathrm{7,} 9$ and 12) and enzyme assay was followed using DNS method under standard conditions at 540nm. One 
enzyme activity unit was defined as the amount of enzyme releasing $1 \mu \mathrm{mol}$ of maltose from substrate in 3 minutes at $\mathrm{pH}$ 6.9 at $20^{\circ} \mathrm{C}$.

\section{Effect of Temperature on Enzyme Activity}

The stability of the enzyme always depends upon the temperature. The influence of temperature on the activity of amylase was determined by incubating the assay reaction mixture at different temperatures $\left(4^{\circ} \mathrm{C}, 28^{\circ} \mathrm{C}, 37^{\circ} \mathrm{C}, 55^{\circ} \mathrm{C}\right.$ and $80^{\circ} \mathrm{C}$ ) and further assayed under standard conditions.

\section{Effect of Activator}

Most amylases are known to be metal ion dependent enzymes $(9,12,16)$. To investigate the effect of activators on enzyme activity, Magnesium Chloride $\left(\mathrm{MgCl}_{2}\right)$ at a concentration of $1 \mathrm{mg} / \mathrm{ml}$ was used as an activator for the enzyme. It was added in different concentrations $(2.12 \mathrm{mM}$, $4.24 \mathrm{mM}, 6.36 \mathrm{mM}, 8.48 \mathrm{mM}$ and $10.6 \mathrm{mM}$ ) to the assay mixture. Amylase activity was then assayed as mentioned earlier to check out for the change in the enzyme activity.

\section{Effect of Inhibitor}

Kinetic analysis (Lineweaver-Burk and Dixon plots) indicated that different inhibitors exhibit different inhibition patterns, as EDTA showed competitive inhibition (11). To investigate the effect of inhibitors on enzyme activity, Ethylene Diamine Tetra Acetic acid (EDTA) was prepared at a concentration of $1 \mathrm{mg} / \mathrm{ml}$ and added in different concentrations (0.538 mM, 1.07 mM, 1.61 mM, 2.15 mM and 2.69 mM) to the assay mixture and measured the amylase activity.

\section{Effect of Substrate Concentration}

Carbon sources influenced amylase production and the most commonly used substrate is starch (2). To investigate the effect of varying concentrations of substrate on enzyme activity, starch was prepared at a concentration of $1 \%(\mathrm{w} / \mathrm{v})$ and this was used in different concentrations $(61.7 \mathrm{mM}, 74.04 \mathrm{mM}$, $86.38 \mathrm{mM}, 98.72 \mathrm{mM}, 111.06 \mathrm{mM}$, and $123.4 \mathrm{mM})$ in the assay mixture and the amylase activity was measured.

\section{RESULTS AND DISCUSSION}

\section{Starch Hydrolysis Test}

The strains showed formation of a halo zone, which indicated the degradation of the starch from the starch agar by the enzyme $\alpha$-amylase produced by Bacillus licheniformis.

\section{Enzyme Production}

In submerged fermentation, the production of the $\alpha$ amylase by the B.licheniformis MTCC strain 2617, using four different substrates as carbon source, reached maximum on the third day (Starch $2.59 \mathrm{IU} / \mathrm{ml} /$ minutes, Rice powder 2.4 $\mathrm{IU} / \mathrm{ml} /$ minutes, Wheat powder $2.23 \mathrm{IU} / \mathrm{ml} / \mathrm{minutes}$, Ragi powder $0.89 \mathrm{IU} / \mathrm{ml} /$ minutes) and the production declined by reaching the minimum on the fifth day (Starch 1.92 $\mathrm{IU} / \mathrm{ml} /$ minutes, Rice powder $1.75 \mathrm{IU} / \mathrm{ml} /$ minutes, Wheat powder $1.13 \mathrm{IU} / \mathrm{ml} /$ minutes, Ragi powder $0.73 \mathrm{IU} / \mathrm{ml} / \mathrm{minutes}$ ). Of the four substrates used, starch gave the highest production of the enzyme on all the days (Figure 1A).

Similarly by submerged fermentation the production of $\alpha$ amylase by the B.licheniformis MTCC strain 2618, using four different substrates as carbon source, reached maximum on the $3^{\text {rd }}$ day (Starch $3.64 \mathrm{IU} / \mathrm{ml} /$ minutes, Rice powder 2.93 $\mathrm{IU} / \mathrm{ml} /$ minutes, Wheat powder $2.67 \mathrm{IU} / \mathrm{ml} /$ minutes, Ragi powder $2.36 \mathrm{IU} / \mathrm{ml} /$ minutes) and the production declined by reaching the minimum on the $5^{\text {th }}$ day (Starch 1.84 $\mathrm{IU} / \mathrm{ml} /$ minutes, Rice powder $1.65 \mathrm{IU} / \mathrm{ml} /$ minutes, Wheat powder $1.19 \mathrm{IU} / \mathrm{ml} /$ minutes, Ragi powder $0.88 \mathrm{IU} / \mathrm{ml} /$ minutes). Of the four substrates used, starch gave the highest production of the enzyme on all the days (Figure 1B).

The production of the $\alpha$-amylase from the two B.licheniformis strains used, MTCC strain 2618 showed the highest production on all the four substrates used as carbon source, i.e., on the $3^{\text {rd }}$ day, the maximum production of the enzyme was seen and of the substrates used the medium containing starch gave the highest production of enzyme. 


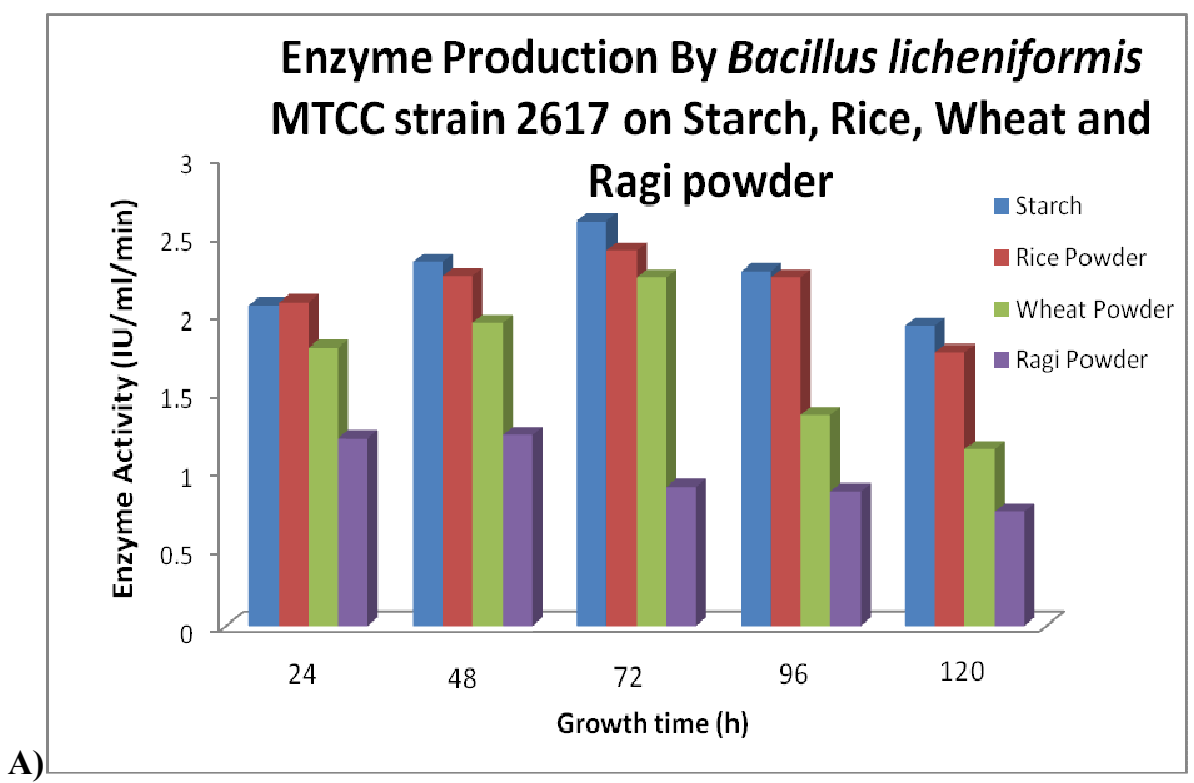

A)

\section{Enzyme Production By Bacillus licheniformis MTCC strain 2618 growing on}
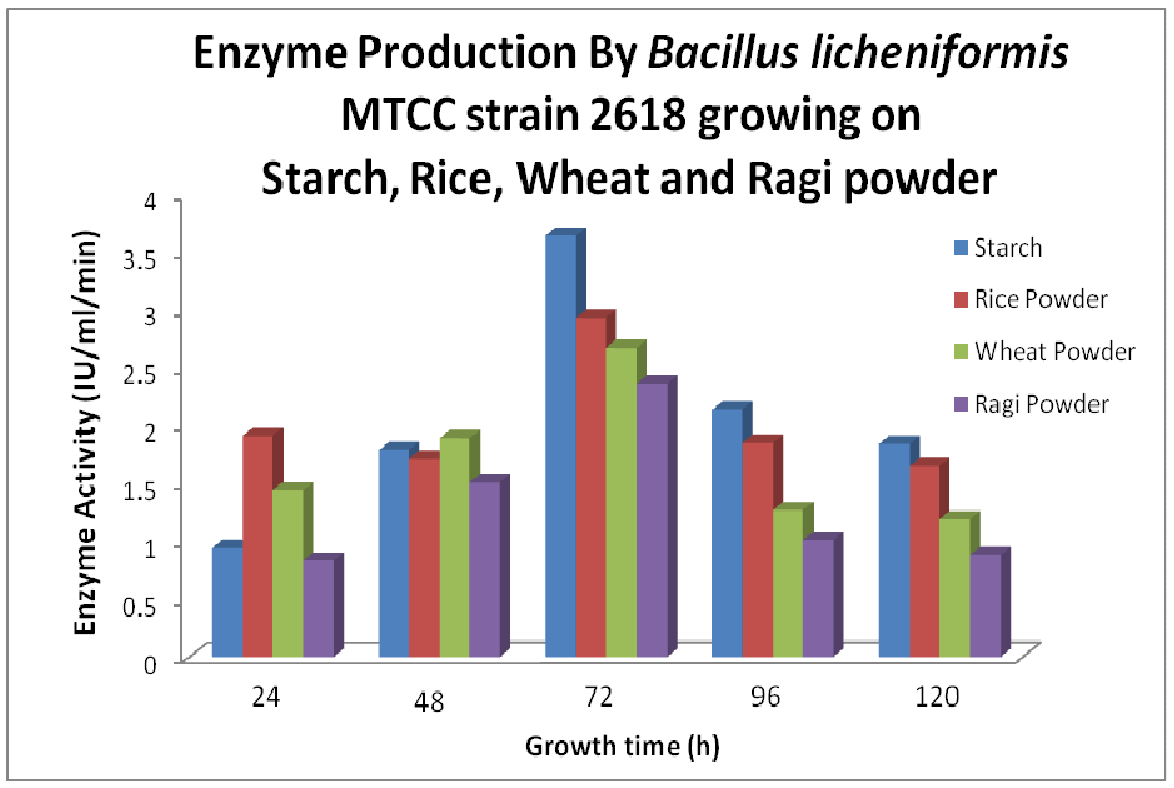

B)

Figure 1. (A) Enzyme production by B.licheniformis MTCC strain 2617. (B) Enzyme production by B.licheniformis MTCC strain 2618

\section{Characterisation}

Of the two B. licheniformis strains used for the production of enzyme, MTCC strain 2618 gave the highest production of the enzyme on all the four different substrates used. Thus for the further characterization of the enzyme activity, the enzyme produced by the MTCC strain 2618 was purified and used.

\section{Effect of pH on Enzyme Activity}

The activity of the enzyme gradually increased, reaching the maximum at $\mathrm{pH} 7$ (Figure 2). Further increase in the $\mathrm{pH}$ resulted in the decrease in the activity of $\alpha$-amylase (23). The enzyme activity was found to be the maximum at $\mathrm{pH} 7$ as reported by Vidyalakshmi et al. 2009 (24). 


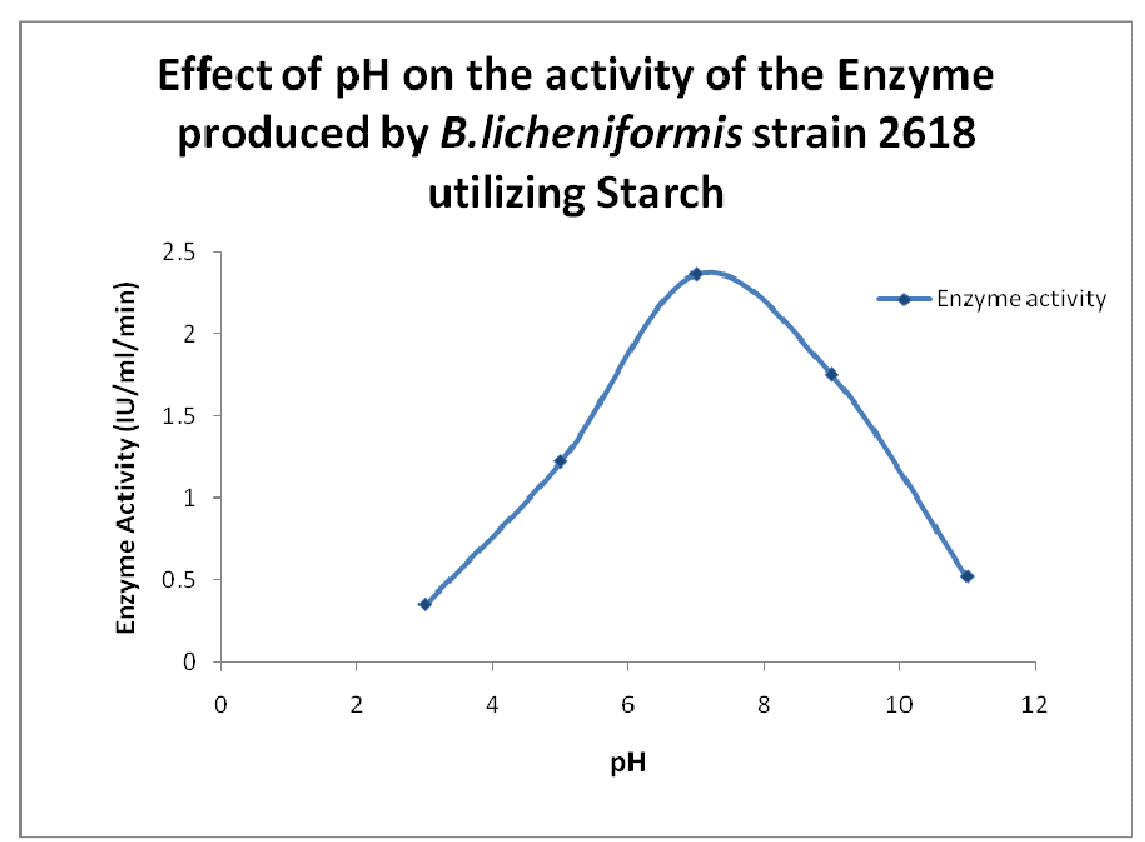

Figure 2. Effect of $\mathrm{pH}$ on the activity of the enzyme.

\section{Effect of Temperature on Enzyme Activity}

Several authors have reported that the majority of the bacterial amylases have an optimum temperature in range of $30-100{ }^{\circ} \mathrm{C}(9,12)$. The effect of temperature on the activity of $\alpha$-amylase was found to be maximum at $37^{\circ} \mathrm{C}$ (Figure 3 ) when compared to $35^{\circ} \mathrm{C}$ as reported by Vidyalakshmi et al., 2009 (24). Activity of $\alpha$-amylase significantly decreased with the increase in the temperature beyond $37^{\circ} \mathrm{C}$.

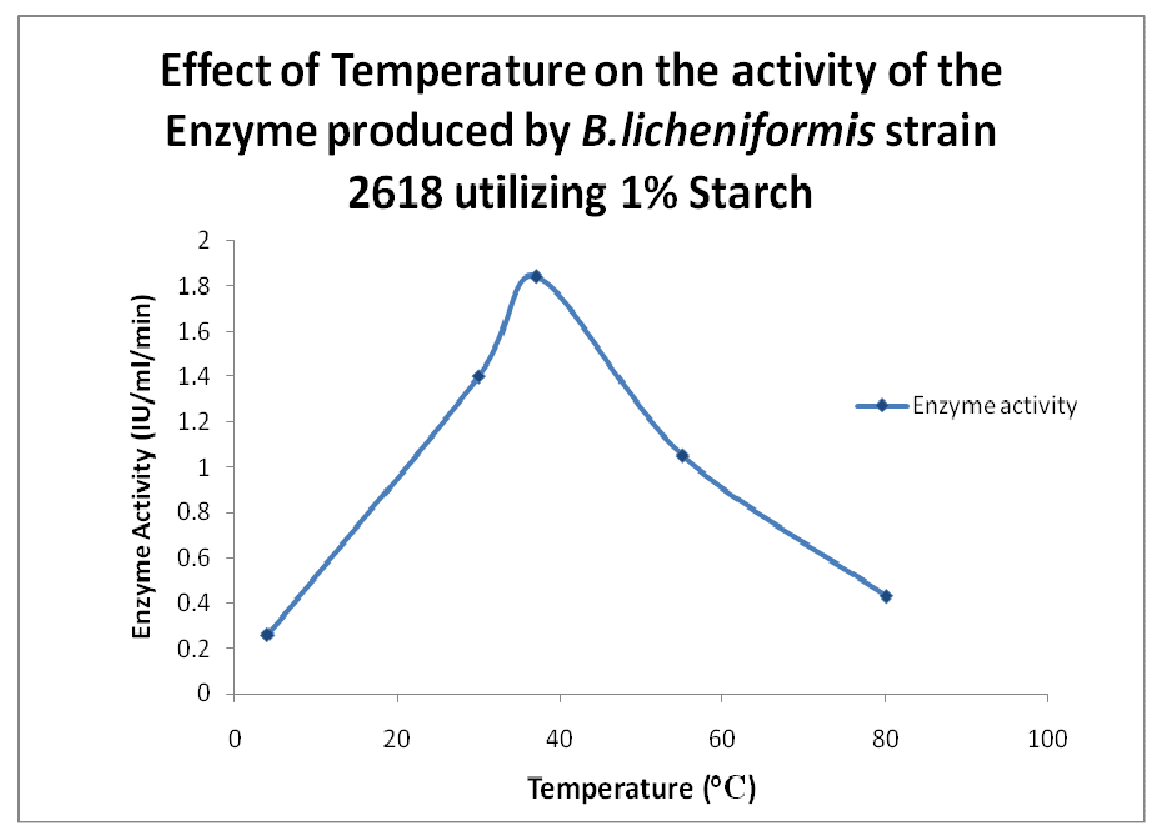

Figure 3. Effect of temperature on the activity of the enzyme. 
Effect of Activator on Enzyme Activity

The enzyme activity increased with the increase in the concentration of the activator (Figure 4), similar to the previous studies showing that $\mathrm{Mg}^{2+}$ ions enhanced amylase activity $(4,13,18)$.

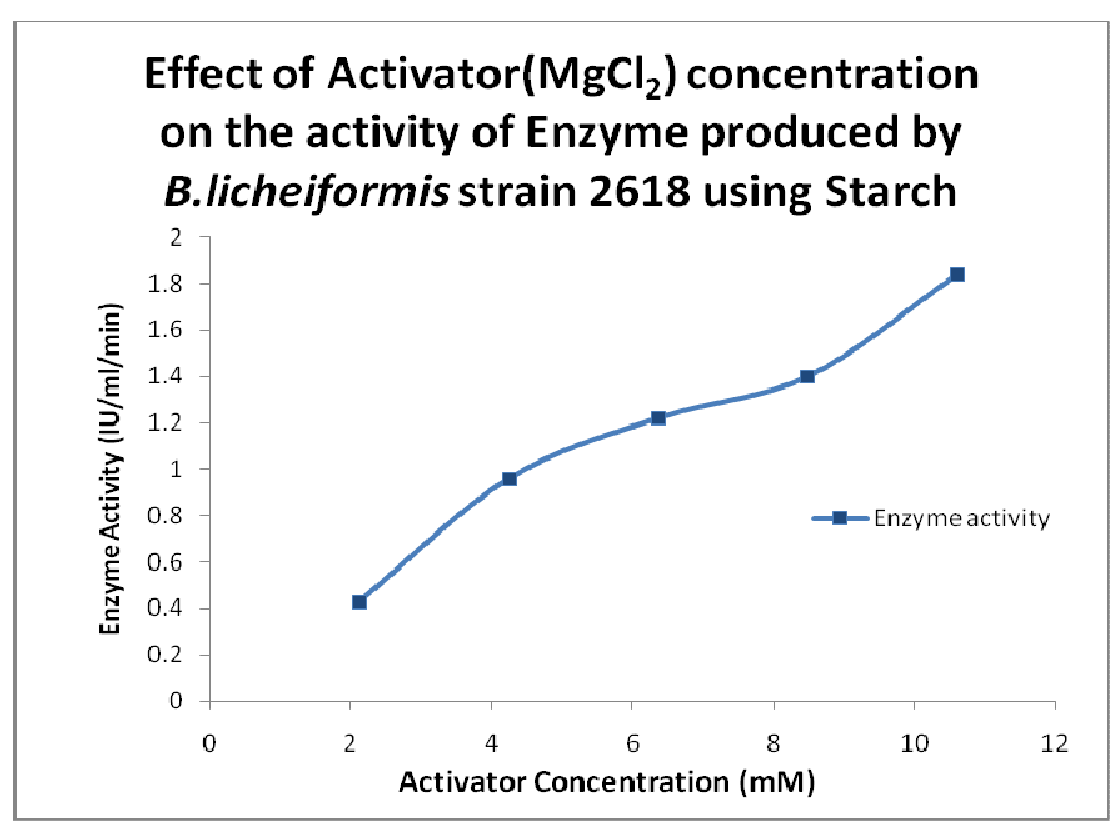

Figure 4. Effect of activator concentration on the activity of the enzyme.

Effect of Inhibitor on Enzyme Activity

The activity of the $\alpha$-amylase decreased with the increase in concentration of the inhibitor (Figure 5) as reported by

Oliveira et al., 2010 (14) and Carvalho et al., 2008 (8).

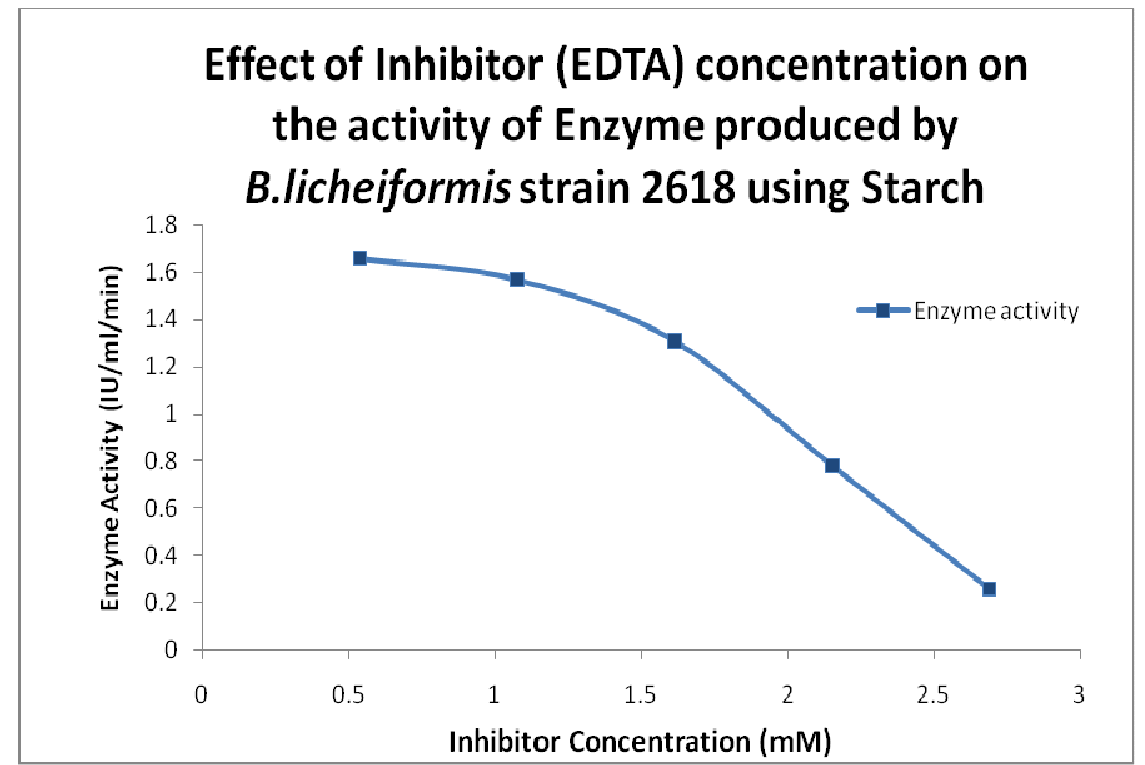

Figure 5. Effect of inhibitor concentration on the activity of the enzyme. 


\section{Effect of Substrate Concentration on Enzyme Activity}

The activity of the $\alpha$-amylase showed increased with increase in the substrate concentration (Figure 6); different from the earlier reports that starch concentration beyond $1 \%$ in medium did not increase the enzyme production (17).

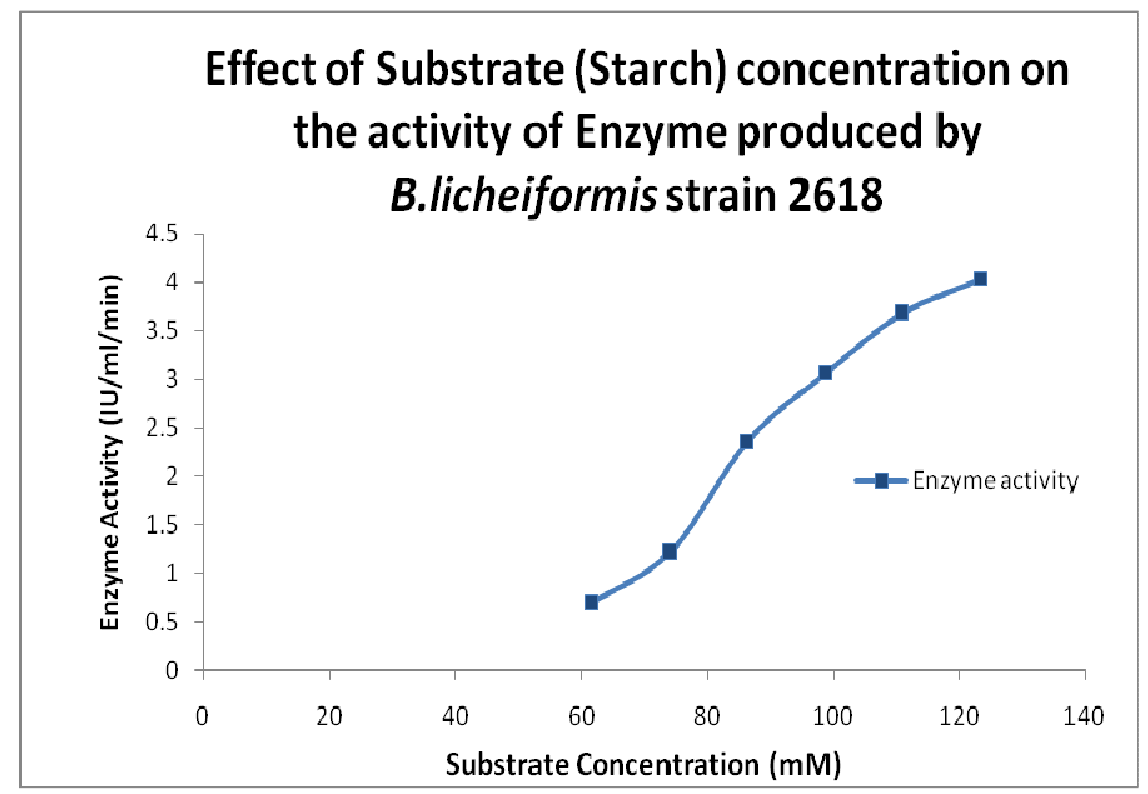

Figure 6. Effect of substrate concentration on the activity of the enzyme.

\section{REFERENCES}

1. Anto, H.; Trivedi, U.; Patel, K.; (2006). $\alpha$-Amylase Production by $B$. cereus, Food Technol. Biotechnol. 44 (2) 241-245.

2. Bajpai, P.; Bajpai, P. (1989). High-temperature alkaline $\alpha$-amylase from Bacillus licheniformis TCRDC-B13. Biotech. Bioeng. 33 (1), 72-78.

3. Bernfeld, P.; (1955). Amylases: $\alpha$ and $\beta$; Method in Enzymology, Vol. 1, Academic Press, USA, pp: 149.

4. Bernharsdotter, E. C. M. J.; Ng, J. D.; Garriott, O. K.; Pusey, M. L. (2005). Enzymic properties of an alkaline chelator-resistant amylase from an alkaliphilic Bacillus sp. isolate L1711. Process Biochem. 40 (7), 2401-2408.

5. Brumm, P. J.; Hebeda, R.E.; Teague, W. M. (1991). Purification \& characterization of commercialized, cloned B. megaterium a-amylase. Part I: Purification \&hydrolytic properties. Starch/Stãerke. 43 (8), 319 323.

6. Burhan, A.I.; Nisa, U.; Gokhan, C.; Omer, C.; Ashabil, A.; Osman, G. (2003). Enzymatic properties of a novel thermostable, thermophilic, alkaline and chelator resistant amylase from an alkaliphilic Bacillus sp. Isolate ANT-6. Process Biochem. 38 (10), 1397-1403.
7. Çalik, P.; Özdamar, T.H. (2001). Carbon sources affect metabolic capacities of Bacillus species for the production of industrial enzymes. Biochem. Eng. J., 8 (1), 61-81.

8. Carvalho, R. V.; Côrrea, T. L. R.; Silva, J. C. M.; Mansur, L. R. C. de O.; Martins, M. L. L. (2008). Properties of an Amylase from Thermophilic Bacillus sp. Braz. J. Microbiol., 39, 102-107

9. Cordeiro, C. A. M.; Martins, M. L. L.; Luciano, A. B. (2002). Production and properties of $\alpha$-amylase from thermophilic Bacillus sp. Braz. J. Microbiol., 33 (1), 57-61.

10. Fogarty, W.M.; Kelly, C.T. (1980). Amylase, amyloglucosidase and related glucanases. Rose A.H. Economic Microbiology, Microbial Enzymes and Bioconversion, Vol 5, Academic Press Inc, New York. 115-170.

11. Gonzalvo, M. C.; Gil, F.; Hernández, A. F.; Villanueva, E.; Pla, A. (1997). Inhibition of paraoxonase activity in human liver microsomes by exposure to EDTA, metals and mercurials. Chem. Biol. Interact., 105 (3), 169-179.

12. Gupta, R.; Gigras, P.; Mohapatra, H.; Goswami, V.K.; Chauhan, B. (2003). Microbial $\alpha$-amylases: a biotechnological perspective. Process Biochem. 38 (11), 1599-1616. 
13. Hards, R. G.; Wright, J. A. (1984). Ribonucleotide reductase activity in intact mammalian cells: stimulation of enzyme activity by $\mathrm{MgCl} 2$, dithiothreitol, and several nucleotides. Arch Biochem Biophys. 231 (1), 9-16.

14. Oliveira, A.N.; Oliveira, L.A.; Andrade, J.S. (2010). Partial Characterization of Amylases of Two Indigenous Central Amazonian Rhizobia strains. Braz. Arch. Biol. Technol. 53 (1), 35-45.

15. Prabakaran, G.; Pugalvendhan R.; (2009). Production and Immobilization of Alpha Amylase by using Bacillus subtilis. Rec Res Sci Tech., 1 (4), 189-194.

16. Ramachandran, S.; Patel, A, K.; Nampoothiri, K, M.; Chandran, S.; Szakacs, G.; Soccol, C, R.; Pandey, A. (2004). Alpha amylase from a fungal culture grown on oil cakes and its properties. Braz. Arch. Biol. Technol. 47 (2), 309-317.

17. Santos, E.O.; Martins, M.L.L. (2003). Effect of the medium composition on formation of amylase by Bacillus sp. J. Braz. Arch. Biol. And Technol. 46 (1), 129-134.

18. Sarikaya, E.; Gürgün, V.; (2000). Increase of the $\alpha$-amylase yield by some Bacillus strains. Turk. J. Biol. 24 (2), 299-308.
19. Shaista, Kokab, M.; Rehman, Asghar, K.; Asad M, J.; and Adedyo, O.; (2003). Alpha Amylase Production from Banana Peel. Int. J. Agri. Biol. 5(1), 36-39.

20. Souza, P. M.; Magalhães, P. O. (2010). Application of Microbial $\alpha$ Amylase In Industry - A Review. Braz. J. Microbiol., 41, 850-861.

21. Takasaki, Y. (1983). An amylase producing maltotetrose and from maltopentose from B. circulans. Agric. Biol. Chem. 47 (10), 2193-2199.

22. Takasaki, Y. (1985). An amylase producing maltotriose from $B$ subtilis. Agric. Biol. Chem. 49 (4), 1091-1097.

23. Teodoro, C.E. de S.; Martins, M. L. L. (2000). Culture Conditions for the Production of Thermostable Amylase by Bacillus sp. Braz. J. Microbiol., 31, 298-302.

24. Vidyalakshmi R.; Paranthaman R.; Indhumathi J. (2009). Amylase Production on Submerged Fermentation by Bacillus spp. World Journal of Chemistry 4 (1), 89-91.

25. Wind, R. D.; Buitelaar, R.M.G.; Huizing, H.J.; Dijkhuizen, L. (1994). Characterization of a new Bacillus stearothermophilus isolate: a highly thermostable $\alpha$-amylase producing strain. Appl. Micrbiol. Biotechnol. 41 (2), 155-162. 